\title{
レーザレンジファインダを用いた歩行計測システムの提案*
}

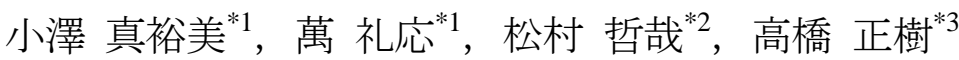

\section{Gait Measurement System Using Laser Range Finder}

\author{
Mayumi OZAWA ${ }^{* 1}$, Ayanori YOROZU, Tetsuya MATSUMURA and Masaki TAKAHASHI \\ ${ }^{* 1}$ Keio University, School of Science for Open and Environmental Systems \\ 3-14-1 Hiyoshi, Kohoku-ku, Yokohama 223-8522, Japan
}

\begin{abstract}
With our society rapidly aging, it is worried that the burden on families who have members in need of nursing care increase. The elderly people sometimes have come to require nursing care caused by falling. To reduce the risk of fallings in elderly, gait training is conducted in community health activities. In order to evaluate the effect of gait training, the measurement system of gait performance is performed. With conventional gait measurement systems using a force plate or a 3-dimensional motion measuring device, it is difficult to introduce in community health activities because of its scale and cost. Therefore, a gait measurement system with easy to use and low cost is needed. In this study, a gait measurement system using a laser range finder (LRF) is proposed. In the proposed system, legs of the subject are detected based on pattern recognition for the range data of LRF. Then, the system obtains the human motions in the horizontal plane and extracts the particular kinematic parameters during walking. To verify the validity of the extracted parameters, the proposed system was applied to the walking test. The subjects walk on the predesignated targets in a verification test. From the results, it was confirmed that the proposed system can measure foot contact time, position and velocity of both legs with accuracy.
\end{abstract}

Key Words : Laser Range Finder, Gait Measurement, Kalman Filter

\section{1. 緒言}

人口の高齢化は現代の日本が抱える大きな社会問題である．特に，要介護者数は老年人口に伴って増加する傾 向があることから，生産年齢人口への経済的，精神的な介護負担の増大が梖念されている. 高齢者が要介護者と なる原因として，脳血管疾患や認知症と並んで，転倒が上位に挙げられる(1). そこで，高齢者の転倒は加齢に伴 う歩行能力の低下に関連があるとする研究(2)(3)に基づいて，実際に，地域保健活動や，高齢者を対象とした通所介 護施設において，高齢者を対象とした歩行訓練が実施されている ${ }^{(4)(5)}$. また，この歩行訓練の介護予防への効果を 評価するために，歩行能力評価や歩行計測が行われている.

従来の歩行分析に関する研究において，定量的に歩行能力を評価する場合に多く用いられる計測装置は，床反 力計や三次元動作計測装置である(6)(7)(8). 各装置の概要図を図 1 に示寸，床反力計は，プレートの四隅に設置され た歪みゲージを利用して, 直交する $x, y, z$ 軸の力と, それらの三軸のモーメントを測定する装置である ${ }^{(9)}$. プレ 一トの鉛直方向の力の割合から床反力作用点の位置を算出でき，歩幅やストライド長，着床時の脚の向きを計測 することが可能であるが，遊脚の移動軌跡など空間的指標を取得することは困難である．一方，三次元動作計測 装置は，被験者の身体に反射マーカを貼り付け，複数台のカメラでマーカを認識することにより，マーカを貼付 した部位の三次元上の空間座標を取得する装置である ${ }^{(9)}$. 取得したマーカ位置座標の分析から, 歩幅やストライ ド長を算出することが可能である.

\footnotetext{
* 原稿受付 2012 年 10 月 26 日

*1 学生員, 慶應義塾大学大学院 理工学研究科（†223-8522 神奈川県横浜市港北区日吉 3-14-1）

*2 慶應義塾大学大学院 理工学研究科

*3 正員, 慶應義塾大学 理工学部

E-mail: takahashi@sd.keio.ac.jp
} 


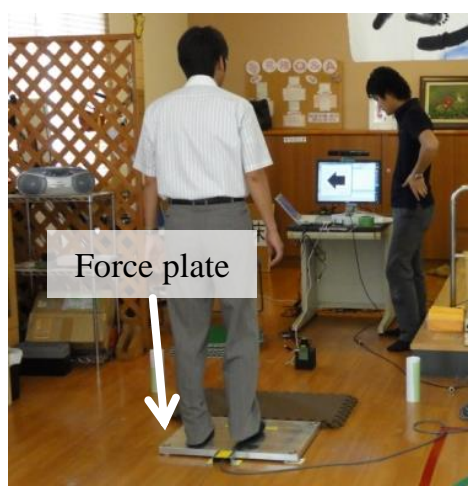

(a) Force plate

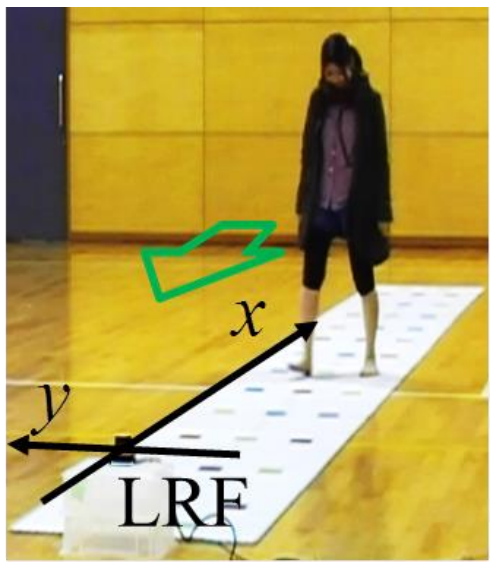

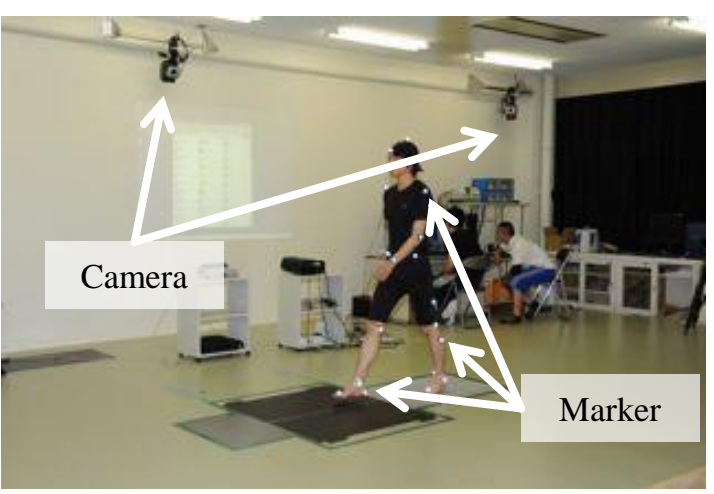

(b) 3-dimensional motion measurement device ${ }^{(10)}$

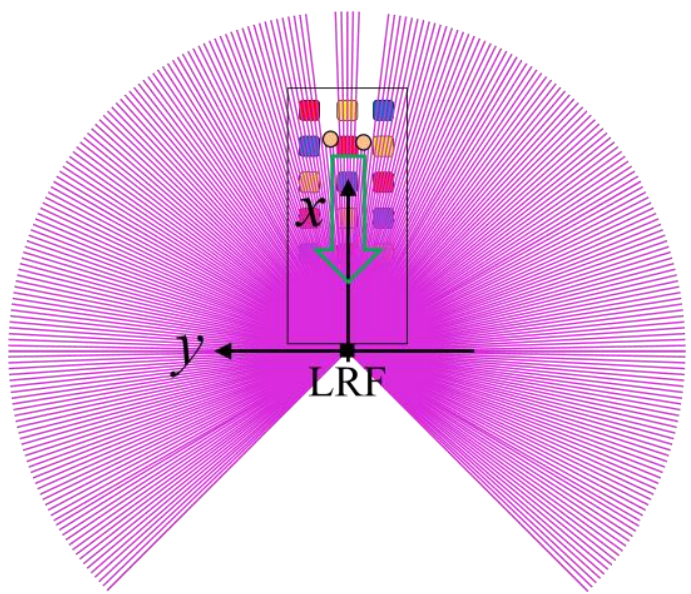

(c) Proposed system

Fig. 1 Gait measurement systems

地域保健活動で実施される歩行計測においては， $3 \mathrm{~m}$ 歩行テストや $5 \mathrm{~m}$ 歩行テストなどの，数メートルの歩行 を計測する方法が代表的である．このような場合に，三次元動作計測装置の場合には，直射日光を避けるため遮 光カーテンを設置するなど, マーカを認識する際に障害となる物がないように環境を整備することや, 図 1 (b) に 示すように複数台のカメラを設置するために広いスペースが必要になるなど, システムが大規模になり，導入コ ストも高くなる. 加えて, カメラのデータを統合し，マーカの三次元座標を取得するために，装置を設置する際 にカメラのキャリブレーションを行い，各カメラの位置や，設置するカメラ間の角度をパラメータとして取得す る必要がある. また, ビデオカメラや三次元動作計測では計測精度を向上させるため, 被験者に反射マーカなど を貼り付ける場合があるが，地域保健活動では被験者が多いため，時間面，高齢者の被験者の方々への負担の面 から望ましいとは言えない。

このように，計測システムの規模が大きく，可搬性が低い，導入コストが高い，などの理由から，予算や計測 に割くことのできる人員, 施設に制限のある地域保健活動で実施される歩行計測においては，従来の定量的な歩 行評価が可能な計測装置の導入は困難である。そのため，現在の地域保健活動においては，ストップウォッチな どを用いた計測者の目視による歩行速度の計測や歩容の観察による評価が行われている. しかし，この計測方法 は，計測やデータの解析が計測者に大きく依存するため，信頼性の高い歩行能力の定量的な評価が困難であると いう問題がある。

このような背景から，大規模な計測システムや計測のためのマーカなどを必要としない，可搬性が高い，導入 コストが低い, といった要件を満たす, 地域保健活動に導入しやすい歩行計測システムが求められている. 地域 保健活動で実施している高齢者の歩行能力評価において, 歩行速度やストライド長が指標とされることが多いた め, これらの特徵量を取得できるシステムであることが求められる. さらに，両脚の移動軌跡を取得することが 求められることもある.

そこで本研究では，レーザレンジファインダ（LRF: Laser Range Finder）を用いた歩行計測システムの提案を行 う。提案システムによる歩行計測の様子を図 1 (c) に示寸. 図中の矢印は被験者の進行方向を示寸. LRF は, 二 


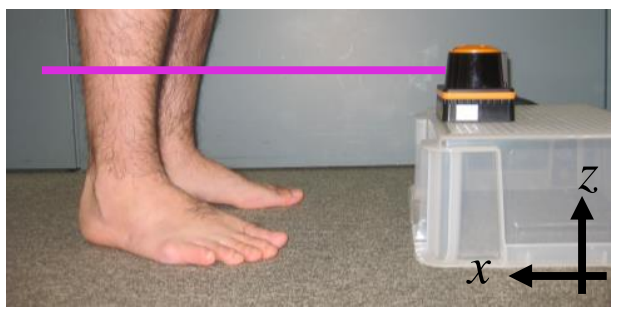

(a) State of measurement

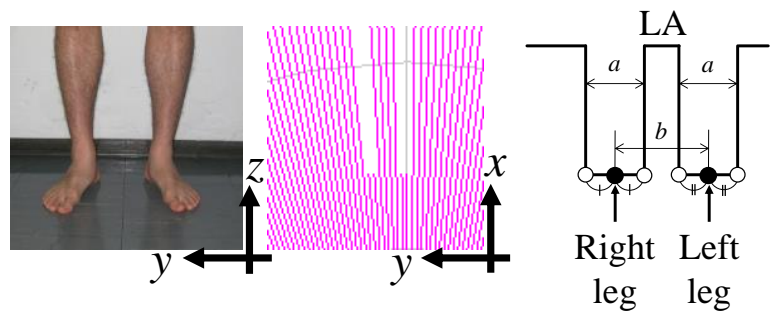

(b) LA (two Legs Apart)

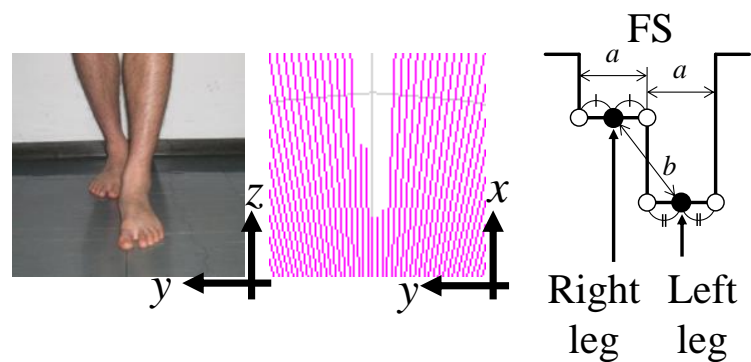

(c) FS (Forward Straddle)
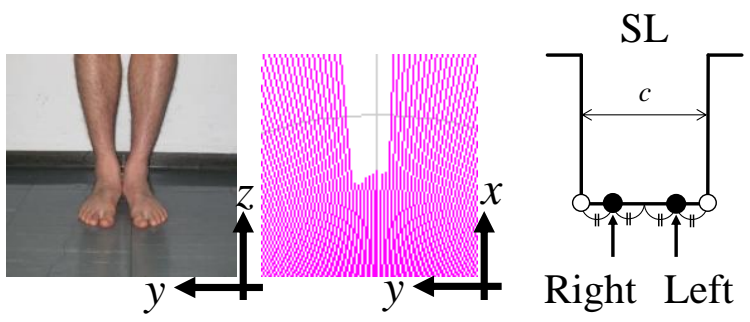

leg leg

Fig. 2 Leg patterns extracted from a LRF

次元平面におけるセンサ周辺の物体までの距離を取得する装置である. 提案システムは，この二次元平面の距離 データを用いて, パターン認識により両脚の位置を取得し，取得した位置情報に基づいて歩行速度やストライド 長を取得する，提案システムは，計測を一台の LRF で行い，装置の設置が容易であるため，歩行の計測に特殊な 環境を構築する必要がない. さらに, 可搬性も高く, 導入コストも低いことから, 地域保健活動への導入が期待 される.

提案システムでは, 被験者の両脚の幅に基づいたパターン認識により両脚を検出し, その位置を取得している. LRF を用いて脚を検出する際に, LRF の角度分解能や被験者の脚の太さによって検出性能が変わるため, 提案シ ステムの計測可能範囲を明らかにする必要がある，そこで，提案システムの事前検証として，脚を想定した静止 物体の計測実験により, 提案システムの計測可能範囲の検証を行う。また, 本稿では, 提案する歩行計測システ ムを図 1 (c) に示寸マット上に一定間隔で配置されたターゲットを踏んで歩くという試験に適用し, 着床時刻お よび計測した歩行速度，ストライド長の妥当性を検証する。

\section{LRF を用いた歩行計測システム}

提案システムの概要を以下に示す.

I. LRF を用いた脚の位置座標取得 $(2 ・ 1$ 節) : LRF を用いて取得した情報から,パターン認識により被験者 の両脚の位置座標を取得する.

II. カルマンフィルタによる位置・速度推定 $(2 \cdot 2$ 節 $)$ : 脚位置データに含まれる LRF の観測雑音などを考慮 して，被験者の両脚の位置および速度を推定する.

III. 脚の着床時刻の取得 $(2 \cdot 3$ 節) : 人間が歩行する際の, 片方の脚の速度履歴の特徵を考慮して, 推定した 脚の速度を解析することにより，着床時刻を取得する.

IV. 歩行の特徵量の取得 $(2 \cdot 4$ 節 $)$ : 取得した着床時刻および, 各着床時刻における脚位置データを用いて, 歩行周期時間，ストライド長，一歩行周期あたりの平均歩行速度を取得する.

\section{2・1 LRF を用いた脚の位置座標取得}

提案システムではまず, LRF を用いて被験者の脚の位置座標を取得する. 取得する各脚の位置座標は, 図 2 に ○で示す点である. 
LRFを地面に対して水平に設置し, 二次元平面の距離データを取得する. 提案する歩行計測システムにおいて, 遊脚の脛の付近を計測することを考慮し， LRF を設置する高さは地面から $0.25 \mathrm{~m}$ とした. 人間が歩行する場合に は, LRF が取得する二次元平面の距離データは, 両脚の位置関係により, 図 2 (b) (d) に示すような特徵的な形 になる. LRF が取得した両脚の特徵的な形を, 図 $2(b) \sim(d)$ に示すような三つの脚パターンに分類することで脚検 出を行う手法が提案されている(11). ここで, LA（two Legs Apart）は両脚が離れている場合に検出される脚パタ ーン, FS (Forward Straddle) は脚が重なる, あるいは交差している場合に検出される脚パターンであり, SL (Single Leg）は，LA および FS パターン以外の状況に検出される脚パターンである.この脚パターンを用いた脚検出ア ルゴリズムにより, 図 2 にで示す各脚の位置座標を取得する.

以下に, 脚の位置座標の取得手順を示寸. 提案システムでは, 以下の $\mathrm{i} \sim$ iii の手順を LRF のサンプリング周期 ごとに行う。

i. LRF から得た距離データからエッジ検出を行う. 図 2 に検出されるエッジを○で示す. 隣接する距離デー タとの差が閾值 $0.1 \mathrm{~m}$ よりも大きかった場合に, エッジを検出する.このとき, LRFから向かって右側の 距離データが大きい場合を右側エッジとし，小さい場合を左側エッジとする.

ii. 図 2 に示す $a, b, c$ に対して, それぞれ条件式 $0.01<a<0.2 \mathrm{~m}, 0.1<b<1.0 \mathrm{~m}, 0.2<c<0.4 \mathrm{~m}$ を満たす とき，右側エッジ・左側エッジの並び方の組み合わせにより， LA, FS，および SL の脚パターンに分類し て脚を検出する.ここで, $a$ は一本の脚の太さ, $b$ は両脚の位置座標間の距離, $c$ は二本の脚の太さを示寸.

iii. エッジの位置情報をもとに，図 2 に○で示寸，右脚および左脚の位置座標をそれぞれ算出する.

\section{$2 \cdot 2$ カルマンフィルタによる位置・速度推定}

$2 ・ 1$ 節の LRF を用いた脚の座標取得には, LRF の観測雑音や, 脚の位置を図 2 のように左右のエッジの中点 から取得することによる影響が含まれるため，これらを考慮した脚の位置・速度を推定する必要がある. 本節で は，カルマンフィルタを用いて被験者の脚位置および速度の推定を行う方法について述べる.

被験者がほぼ一定の速度で歩行すると仮定すると，以下の状態方程式が得られる.

$$
\boldsymbol{x}(k)=\boldsymbol{A} \boldsymbol{x}(k-1)+\boldsymbol{B} \boldsymbol{v}(k-1)
$$

ここで，状態変数 $\boldsymbol{x}=\left[\begin{array}{llll}p_{x}^{i} & p_{y}^{i} & v_{x}^{i} & v_{y}^{i}\end{array}\right]^{T}$ は各脚の位置および速度であり，上添え字の $i$ は $R$ が右脚， $L$ が左脚を表 し, 下添え字は $x$ 成分, $y$ 成分を表す. システム雑音 $\boldsymbol{v}=\left[\begin{array}{ll}n^{v_{x}} & n^{v_{y}}\end{array}\right]^{T}$ は平均值 0 , 分散 $\sigma_{v}^{2}$ の正規性白色雑音である と仮定する. また，LRFから取得した距離データにより脚位置を検出した時間間隔を $\Delta t$ とするとシステム行列は 以下となる。

$$
\boldsymbol{A}=\left[\begin{array}{cccc}
1 & 0 & \Delta t & 0 \\
0 & 1 & 0 & \Delta t \\
0 & 0 & 1 & 0 \\
0 & 0 & 0 & 1
\end{array}\right], \boldsymbol{B}=\left[\begin{array}{cc}
0 & 0 \\
0 & 0 \\
1 & 0 \\
0 & 1
\end{array}\right]
$$

LRF を用いて取得した被験者の各脚の位置を $\boldsymbol{y}=\left[\begin{array}{ll}p_{x}^{\prime \prime} & p_{y}^{i \prime}\end{array}\right]^{T}(i=R, L)$ とすると，以下の観測方程式が成立する.

$$
\boldsymbol{y}(k)=\boldsymbol{C} \boldsymbol{x}(k)+\boldsymbol{w}(k)
$$

ただし, 観浿雑音 $\boldsymbol{w}=\left[\begin{array}{ll}n^{p_{x}} & n^{p_{y}}\end{array}\right]^{T}$ は平均值 0 , 分散 $\sigma_{w}^{2}$ の正規性白色雑音であると仮定する. $\boldsymbol{C}$ は以下となる.

$$
\boldsymbol{C}=\left[\begin{array}{llll}
1 & 0 & 0 & 0 \\
0 & 1 & 0 & 0
\end{array}\right]
$$




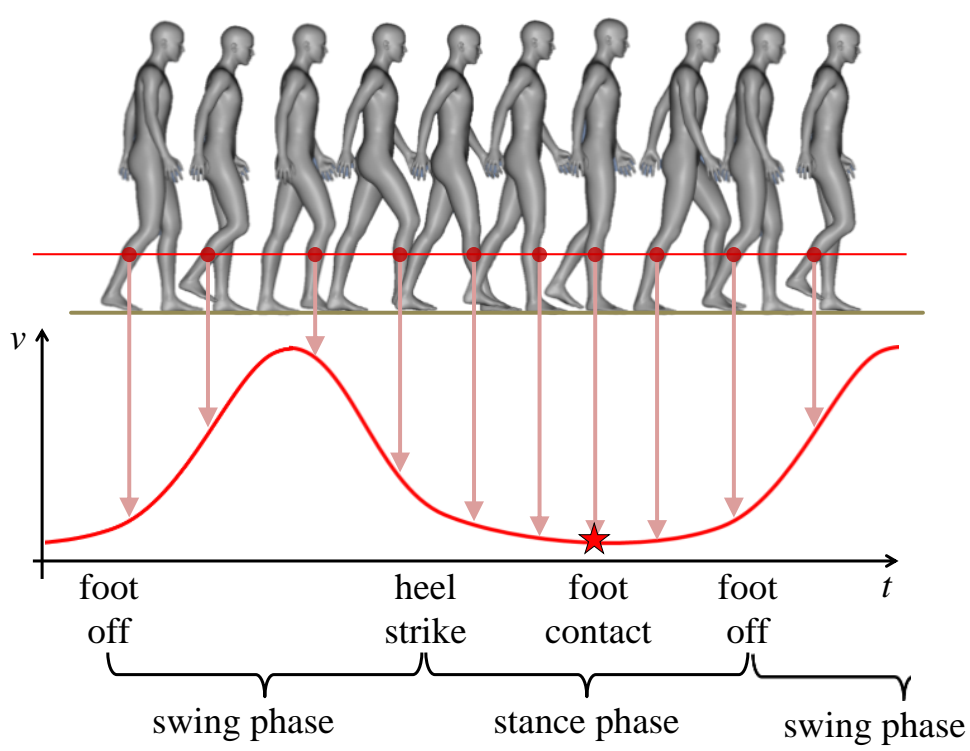

Fig. 3 Gait velocity diagram of one leg

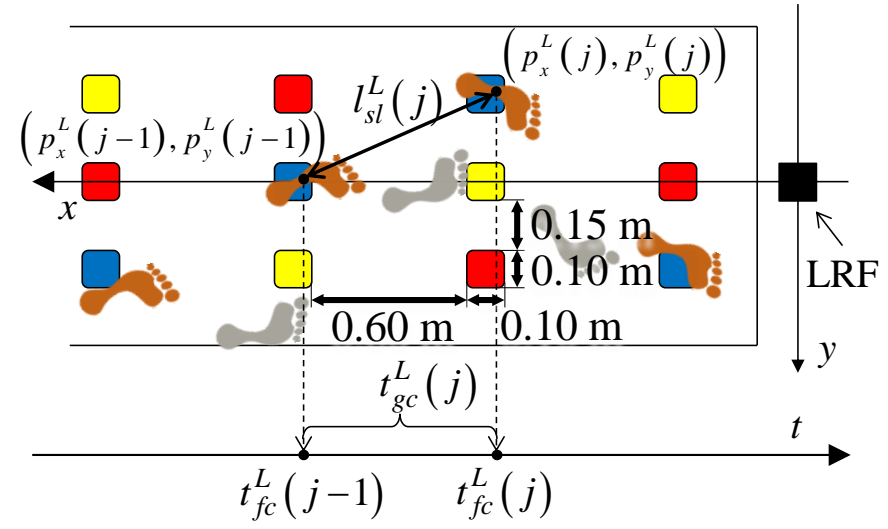

Fig. 4 Parameters for gait performance

\section{$2 \cdot 3$ 脚の着床時刻の取得}

従来の歩行分析では，歩行の状態の区別に脚の着床時刻や離床時刻を利用することが多い，特に，歩行能力評 価においては，歩幅やストライド長を評価の指標として採用することが多いため，これらの特徴量を取得するた めに, 着床時刻もしくは離床時刻を取得する必要がある. 本節では, 提案システムにおける, 対象脚の着床時刻 の取得について述べる.

図 3 に示すように，歩行時の脚の状態は，一歩行周期（たとえば，対象とする脚の足部着床から，次の同側の 足部着床まで）の中で，遊脚期と立脚期に分類される．脛の高さの水平面における歩行時の片脚の速度に着目す ると，遊脚期には，まず加速した後に減速し，立脚期に移行する．立脚期には，低速で運動した後，加速して遊 脚期に移行する. 歩行時には, この運動を周期的に繰り返し行う.したがって, 脚の速度情報の解析により, 着 床時刻 $t_{f c}^{i}(i=R, L)$ を取得することができると考えられる．提案システムでは，対象脚の速度が極小值をとる時刻 を求めることで，着床時刻を取得する.

\section{$2 \cdot 4$ 歩行の特徴量の取得}

本節では，取得した着床時刻 $t_{f c}^{i}$ を用いた，歩行の特徴量の取得について述べる. 図 4 に左脚 $(i=L)$ の $j$ 番目 のステップにおける各特徵量を示す.

一ストライドに要する時間，すなわち歩行周期時間 $t_{g c}^{i}(i=R, L)$ を以下のように求める. 
Table 1 Specification of LRF (HOKUYO, UHM-08LX)

\begin{tabular}{|l|l|}
\hline \multirow{2}{*}{ Detection range } & $\begin{array}{l}0.03 \text { to } 11.0 \mathrm{~m} \\
270 \mathrm{deg}\end{array}$ \\
\hline \multirow{3}{*}{ Accuracy } & 0.1 to $1.0 \mathrm{~m}: \pm 0.03 \mathrm{~m}$, \\
\cline { 2 - 2 } & 1.0 to $8.0 \mathrm{~m}: 3 \%$ of measured distance \\
\hline Angular resolution & $0.36 \mathrm{deg}(360 \mathrm{deg} / 1024$ steps $)$ \\
\hline Scan time & $67 \mathrm{~ms} / \mathrm{scan}$ \\
\hline
\end{tabular}

$$
t_{g c}^{i}(j)=t_{f c}^{i}(j)-t_{f c}^{i}(j-1)
$$

次に，着床時刻における脚位置を用いることにより，ストライド長 $l_{s l}^{i}(i=R, L)$ を以下のように求める.

$$
l_{s l}^{i}(j)=\sqrt{\left(p_{x}^{i}(j)-p_{x}^{i}(j-1)\right)^{2}+\left(p_{y}^{i}(j)-p_{y}^{i}(j-1)\right)^{2}}
$$

さらに, ストライド長 $l_{s l}^{i}$ と同様に, 歩行能力評価において代表的な指標である一歩行周期あたりの平均歩行速 度 $v^{i}$ は, 歩行周期時間 $t_{g c}^{i}$ とストライド長 $l_{s l}^{i}$ の商によって以下のように求める.

$$
v^{i}(j)=\frac{l_{s l}^{i}(j)}{t_{g c}^{i}(j)}
$$

\section{LRF を用いた脚の位置計測に関する検証}

提案システムでは，被験者の脚の幅に基づいたパターン認識により両脚を検出し，その位置を取得している. LRF を用いて脚を検出する際に, LRF の角度分解能や被験者の脚の太さによって検出性能が変わるため, 提案シ ステムの計測可能範囲を明らかにする必要がある.ここでは, 表 1 に示すLRF の仕様と脚の太さから検証する計 測範囲を決定し, 脚を想定した静止物体の計測実験により, 静止物体に対する計測精度の観点から, 提案システ ムの計測可能範囲について検証する.

\section{$3 \cdot 1$ 計測範囲の決定}

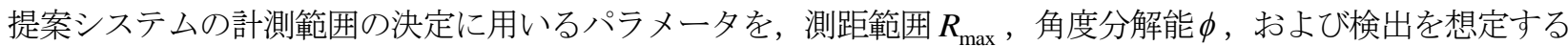
物体の幅 $W$ とする. LRF から計測を行う物体までの距離を $R_{l}$ とすると, 検出において左右のエッジを取得するた めには，LRFが物体の少なくとも三力所の距離データを取得する必要があり，

$$
3 \times 2 \pi R_{l} \times \frac{\phi}{360}<W,\left(0<R_{l}<R_{\max }\right)
$$

を満たす必要がある. したがって，計測範囲 $R_{m}$ を以下の式を用いて決定する.

$$
R_{m}<\frac{60 W}{\pi \phi},\left(0<R_{m}<R_{\max }\right)
$$

本検証においては，使用する $\mathrm{LRF}$ の仕様より $\phi=0.36 \mathrm{deg}, R_{\max }=8.0 \mathrm{~m}$ ，物体の幅を人間の下腿の最大囲の 平均值 ${ }^{(12)}$ より $W=0.10 \mathrm{~m}$ とした．以上のパラメータより，計測範囲は $R_{m}=5.0 \mathrm{~m}$ と算出された. 

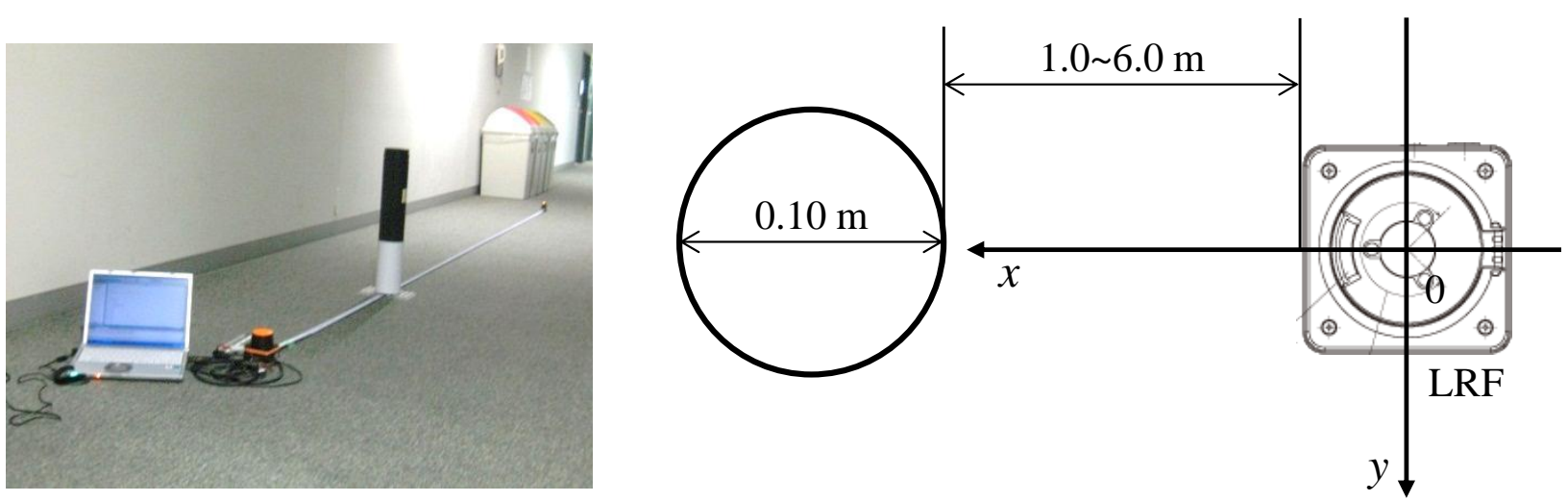

Fig. 5 Experimental situation

Table $2 x$-coordinate of detected position

\begin{tabular}{c|c|c|c|c|c|c|c}
\hline \multirow{2}{*}{\multicolumn{2}{c|}{}} & \multicolumn{7}{c|}{ Mean [m] } & \multicolumn{3}{c}{ SD [m] } \\
\cline { 3 - 8 } \multicolumn{2}{c}{ Position [m] } & \multicolumn{7}{c}{$y$} \\
\cline { 2 - 8 } \multicolumn{1}{c|}{} & 0.0 & 0.2 & 0.4 & 0.0 & 0.2 & 0.4 \\
\hline \multirow{4}{*}{$x$} & 4.0 & 4.01 & 3.95 & 3.95 & $6.14 \times 10^{-3}$ & $2.56 \times 10^{-3}$ & $2.94 \times 10^{-3}$ \\
\cline { 2 - 8 } & 4.5 & 4.54 & 4.45 & 4.47 & $2.84 \times 10^{-3}$ & $5.39 \times 10^{-3}$ & $3.37 \times 10^{-3}$ \\
\cline { 2 - 8 } & 5.0 & 5.02 & 5.00 & 4.96 & $3.50 \times 10^{-3}$ & $4.92 \times 10^{-3}$ & $3.26 \times 10^{-3}$ \\
\cline { 2 - 8 } & 5.5 & - & - & - & - & - & - \\
\cline { 2 - 8 } & 6.0 & - & - & - & - & - & - \\
\hline
\end{tabular}

Table $3 \quad y$-coordinate of detected position

\begin{tabular}{c|c|c|c|c|c|c|c}
\hline \multirow{2}{*}{} & \multicolumn{5}{c|}{ Mean [m] } & \multicolumn{3}{c}{ SD [m] } \\
\cline { 3 - 8 } \multicolumn{2}{c}{ Position [m] } & \multicolumn{5}{c}{$y$} \\
\cline { 3 - 8 } \multicolumn{2}{c|}{} & 0.0 & 0.2 & 0.4 & 0.0 & 0.2 & 0.4 \\
\hline \multirow{4}{*}{$x$} & 4.0 & $7.38 \times 10^{-2}$ & $1.88 \times 10^{-1}$ & $3.83 \times 10^{-1}$ & $1.13 \times 10^{-4}$ & $1.22 \times 10^{-4}$ & $2.85 \times 10^{-4}$ \\
\cline { 2 - 8 } & 4.5 & 0.0 & $1.84 \times 10^{-1}$ & $3.91 \times 10^{-1}$ & 0.0 & $2.23 \times 10^{-4}$ & $2.91 \times 10^{-4}$ \\
\cline { 2 - 8 } & 5.0 & $4.73 \times 10^{-2}$ & $2.07 \times 10^{-1}$ & $3.89 \times 10^{-1}$ & $4.73 \times 10^{-5}$ & $2.04 \times 10^{-4}$ & $2.55 \times 10^{-4}$ \\
\cline { 2 - 8 } & 5.5 & - & - & - & - & - & - \\
\cline { 2 - 8 } & 6.0 & - & - & - & - & - & - \\
\hline
\end{tabular}

\section{$3 \cdot 2$ 検証方法}

計測環境を図 5 に示す．片脚を想定し，直径 $0.10 \mathrm{~m}$ の円筒を LRF の前方に設置する．LRF が取得した距離デ 一タを用いて, 円筒の位置の $x$ 座標および $y$ 座標を取得する. 取得した 150 サンプリング分のデータの平均值 Mean および標準偏差 SD を算出する. 円筒は LRF から $x$ 座標は $1.0 \mathrm{~m}$ から $6.0 \mathrm{~m}$ まで $0.5 \mathrm{~m}$ 刻み, $y$ 座標は $0.0 \mathrm{~m}$ から $0.4 \mathrm{~m}$ まで $0.2 \mathrm{~m}$ 刻みで設置した。

\section{$3 \cdot 3$ 検証結果 $\cdot$ 考察}

LRF を用いて取得した円筒の位置の $x$ 座標および $y$ 座標について, 円筒を $x$ 座標が $4.0 \mathrm{~m}$ から $6.0 \mathrm{~m}$ まで設置 した際の，150 サンプリング分のデータの平均值 Mean および標準偏差 SD を表 2 および表 3 に示す. 表 2 および 表 3 より，0.10 m の円筒は $5.5 \mathrm{~m}$ より先では十分に検出できず， $3 ・ 1$ 節で示した計測範囲が妥当であることを実 験結果より確認した。 


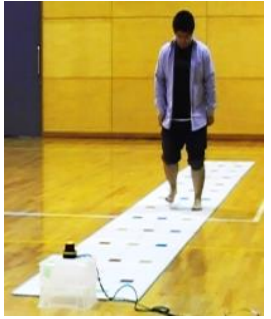

(a) Subject $\mathrm{A}$

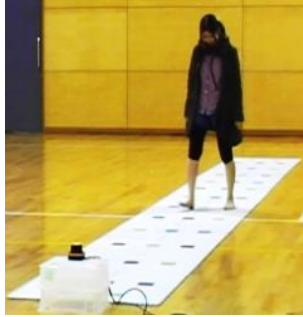

(b) Subject B

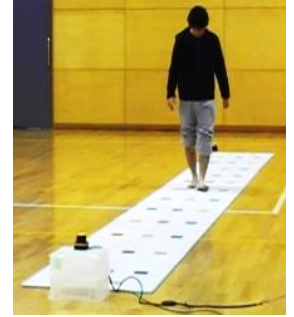

(c) Subject C

Fig. 6 State of experiment

\section{4. 歩行試験への適用による提案システムの検証}

提案する歩行計測システムでは，着床時刻に基づいて歩行周期時間を取得し，着床時刻における脚の位置の情 報に基づいてストライド長を取得する．さらに，歩行周期時間およびストライド長から一歩行周期あたりの平均 歩行速度を取得する，そこで，はじめに，実際の歩行試験において着床時刻の妥当性の検証を行い，次に，ス卜 ライド長の妥当性の検証を行う。

\section{4:1 検証方法}

22 24 歳の男性 7 名, 女性 1 名の計 8 名の被験者で実験を行った．計測環境を図 6 に示寸. LRF は，被験者前 方，遊脚の脛を計測することを考慮して，床から $0.25 \mathrm{~m}$ の高さに設置し， 3 章の LRF の計測範囲の結果を考慮し て, 長さ約 $5.0 \mathrm{~m}$, 幅約 $1.5 \mathrm{~m}$ のマット上を歩行する際の計測を行う. マット上には $0.10 \mathrm{~m}$ 四方のターゲットが 左右 $0.15 \mathrm{~m}$, 前後 $0.60 \mathrm{~m}$ の間隔で配置されている. 被験者には, ターゲットを左脚の踵で踏むように指示し, 歩 き方および歩行速度については特に指示を与えていない，被験者は計測者の合図で歩行を開始し，指定された夕 ーゲットを踏みながらゴール地点へと移動する.

被験者が計測者の合図で歩行を開始してからゴール地点に移動するまで, LRFを用いて距離データを取得する. 取得したデータを用いて $2 \cdot 1$ 節に示した脚検出を行い, $2 \cdot 2$ 節に示したカルマンフィルタによる被験者の両脚 の位置・速度推定を行う。ここで，3 章において LRF を用いた静止物体の計測データの標準偏差を求めたが，本 検証では被験者が歩行する場合の両脚という動的な物体を対象とするため, カルマンフィルタにおける各雑音 $n^{v_{x}}, n^{v_{y}}, n^{p_{x}}$, および $n^{p_{y}}$ は, 動的な対象を扱っている文献(11)(13)を参考にし, 平均值を 0 , 標準偏差を $\sigma_{v_{x}}=\sigma_{v_{y}}=0.1 \mathrm{~m} / \mathrm{s}, \quad \sigma_{p_{x}}=\sigma_{p_{y}}=0.03 \mathrm{~m}$ と試行錯誤的に決定した. また，時間間隔は $\Delta t=0.067 \mathrm{~s}$ とした.

提案システムは, LRF を用いた脚検出の結果に基づいて両脚の距離データを取得し，カルマンフィルタによる状 態推定值に基づいて, 着床時刻を取得する. したがって, 取得した着床時刻における着床位置が，指定したター ゲット内にあることを確認することにより, 着床時刻の妥当性を検証する. また, 実験の際, 被験者にターゲッ トを踵で踏むように指示をしたことから，着床時刻において，踵の位置と LRF で取得する位置はほぼ同じである と仮定した．これにより，ビデオカメラにより測定の様子を撮影し，指定したすべてのターゲットを正しく踏ん でいることを確認した被験者のデータのみを用いて, 取得したストライド長をターゲット間の距離と比較するこ とにより，取得したストライド長の妥当性の検証を行った。また，取得した着床時刻および着床位置の情報に基 ついて，歩行周期時間，ストライド長，一歩行周期あたりの平均歩行速度を算出する.

\section{$4 \cdot 2$ 検証結果 $\cdot$ 考察}

実験結果の一例として，ある被験者で実験を行った際の左脚の速度の時刻歴を図 7 に示し，二次元平面上にお ける左脚の移動軌跡を図 8 に示す. 図 7 において, 点線と*は脚の取得位置の座標から単純な差分によって算出 した速度，実線と口はカルマンフィルタを用いて推定した速度を表す．図中のくはカルマンフィルタを用いない 場合の速度の極小值，云はカルマンフィルタによって求めた速度の推定值の極小值を示す. 図 8 (a) は開始から 終了までの移動軌跡であり, 図 8 (b) は図 8 (a) の一部を拡大したものである. 点線が脚検出アルゴリズムを用い た脚の取得位置の軌跡を表しており，実線がカルマンフィルタを用いて推定した軌跡を表している．図中のくは カルマンフィルタを用いない場合に速度が極小值を取る時刻において取得した位置，污はカルマンフィルタに 

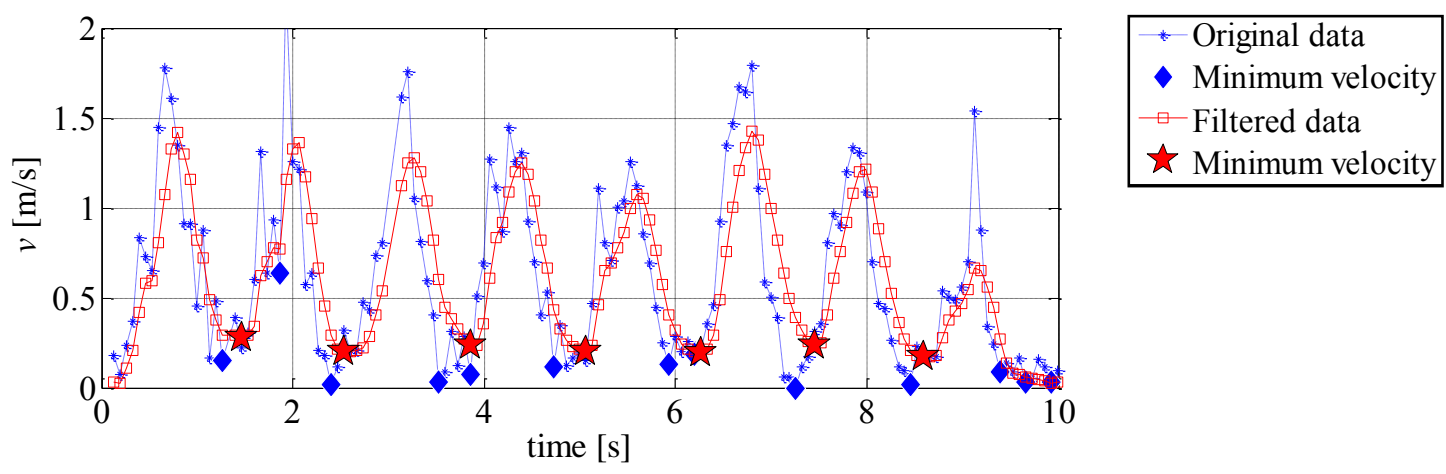

Fig. 7 Time history of estimated gait velocity

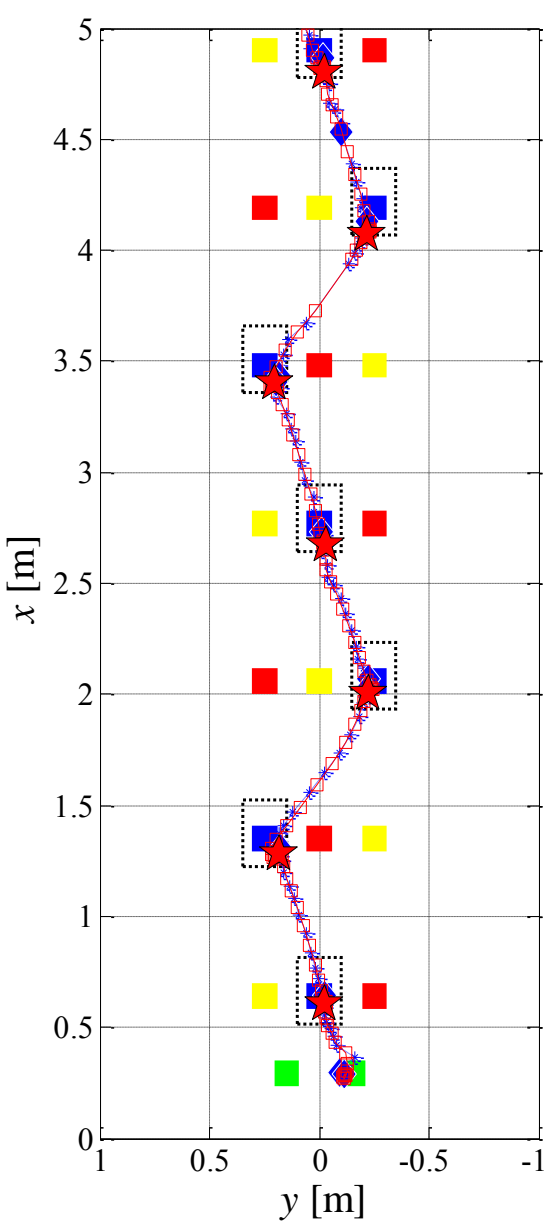

(a)

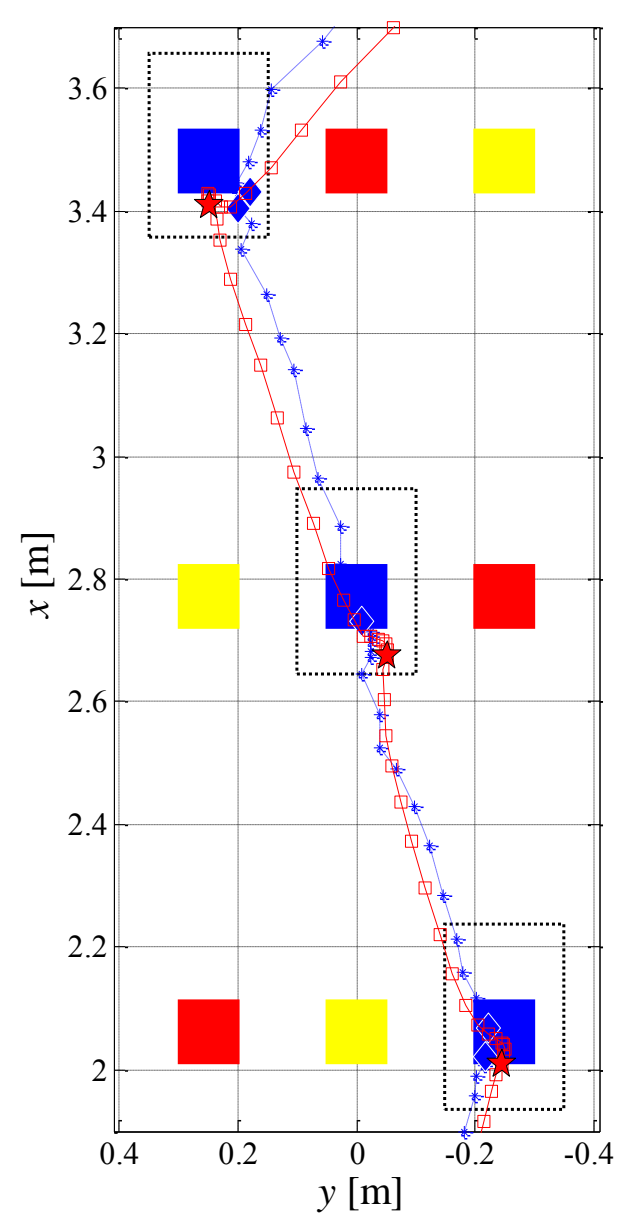

(b)

Fig. 8 Trajectory of estimated leg position

\section{よって求めた速度の推定值が極小值を取る時刻において取得した位置を示す。}

提案システムでは速度が極小值をとる時刻を着床時刻と定義しているが，図 7 より，カルマンフィルタを用い ない場合には，算出した速度に含まれる雑音の影響が大きく，一歩行周期の中で二回，着床時刻を取得してしま うことが確認できる。, 一方, 提案システムでは一歩行周期あたり一回着床時刻を取得できており, かつ, その着 床時刻に基づいて取得した着床位置が指定したターゲット内に入っていることから, 着床時刻の妥当性を確認し た. 
Table 4 Gait cycle time [s]

\begin{tabular}{c|c|c|c|c|c|c}
\hline \multirow{2}{*}{ Subject } & \multicolumn{7}{|c}{ Step } \\
\cline { 2 - 7 } & 1 & 2 & 3 & 4 & 5 & 6 \\
\hline $\mathrm{A}$ & 1.07 & 1.33 & 1.20 & 1.20 & 1.20 & 1.13 \\
\hline $\mathrm{B}$ & 1.13 & 1.07 & 1.00 & 1.20 & 1.13 & 1.07 \\
\hline $\mathrm{C}$ & 1.07 & 1.13 & 0.93 & 1.07 & 1.13 & 0.93 \\
\hline
\end{tabular}

Table 5 Stride length [m]

\begin{tabular}{cc|c|c|c|c|c|c}
\hline & & \multicolumn{7}{c}{ Step } & \multicolumn{1}{c}{} \\
\cline { 2 - 8 } & & 1 & 2 & 3 & 4 & 5 & 6 \\
\hline \multirow{3}{*}{ Subject } & $\mathrm{A}$ & 0.73 & 0.85 & 0.79 & 0.69 & 0.87 & 0.72 \\
\cline { 2 - 8 } & $\mathrm{B}$ & 0.73 & 0.83 & 0.70 & 0.77 & 0.87 & 0.66 \\
\cline { 2 - 8 } & $\mathrm{C}$ & 0.74 & 0.86 & 0.72 & 0.76 & 0.87 & 0.72 \\
\hline \multicolumn{2}{c|}{$l_{d}$} & 0.74 & 0.86 & 0.74 & 0.74 & 0.86 & 0.74 \\
\hline \multicolumn{2}{c|}{ Mean } & 0.73 & 0.85 & 0.74 & 0.74 & 0.87 & 0.70 \\
\hline \multicolumn{2}{c|}{ SD } & $5.20 \times 10^{-3}$ & $1.24 \times 10^{-2}$ & $3.90 \times 10^{-2}$ & $3.38 \times 10^{-2}$ & $2.20 \times 10^{-3}$ & $2.78 \times 10^{-2}$ \\
\hline
\end{tabular}

Table 6 Gait velocity $[\mathrm{m} / \mathrm{s}]$

\begin{tabular}{c|c|c|c|c|c|c}
\hline \multirow{2}{*}{ Subject } & \multicolumn{7}{|c}{ Step } \\
\cline { 2 - 7 } & 1 & 2 & 3 & 4 & 5 & 6 \\
\hline A & 0.68 & 0.64 & 0.66 & 0.58 & 0.73 & 0.63 \\
\hline B & 0.64 & 0.78 & 0.70 & 0.64 & 0.77 & 0.62 \\
\hline C & 0.69 & 0.76 & 0.77 & 0.71 & 0.77 & 0.77 \\
\hline
\end{tabular}

図 8 より，提案システムでは，遊脚の移動軌跡の取得が可能であり，歩行分析における空間的指標を提示可能 であることが確認できた.

また，代表する三人の被験者 $\mathrm{A} ， \mathrm{~B} ， \mathrm{C}$ の計測した歩行周期時間を表 4 に，ストライド長を表 5 に，歩行速度 を表 6 に示寸. また, 表 5 には, 各ターゲット間の距離 $l_{d}$, 同一ターゲット間におけるストライド長の平均值 Mean および標準偏差 SD を示す.

表 5 より，ストライド長について，平均值 Mean が各ターゲット間の距離 $l_{d}$ に近く，標準偏差 SD が小さいこ とから, 取得したストライド長の妥当性を確認した. 歩行周期時間は一ストライドにかかる時間であることから， 表 4 に示寸, 取得した歩行周期も妥当であると考えられる. また, 歩行速度はストライド長と歩行周期時間から 求めるため, 表 6 に示寸, 取得した歩行速度も妥当である.

\section{5. 結}

本研究では，大規模な計測システムや計測のためのマーカなどを必要としない，可搬性が高い，低コストでの 導入が可能である, といった要件を満たし，かつ定量的な歩行能力評価を行うことのできる歩行計測システムの 提案を目的とし，レーザレンジファインダ (LRF: Laser Range Finder) を用いた歩行計測システムの提案を行った.

提案システムでは，LRF を用いた被験者の両脚の位置座標取得および，カルマンフィルタによる被験者の両脚 の位置および速度の推定を行い，人間が歩行する際の脚の速度の特徵を考慮して，推定した速度が極小值をとる 時刻を脚の着床時刻とした。 また，算出した着床時刻から歩行周期時間，着床位置を求めることで，ストライド 長および，一歩行周期の平均歩行速度を取得した。 
提案システムでは, 被験者の両脚の幅に基づいたパターン認識により両脚を検出し,その位置を取得している. LRF を用いて脚を検出する際に, LRF の角度分解能や被験者の脚の太さによって検出性能が変わるため, 提案シ ステムの計測可能範囲を明らかにする必要がある. 本稿では, LRF を用いて一本の脚を想定した直径 $0.10 \mathrm{~m}$ の円 筒の計測実験により, 使用する LRF の測距範囲, 角度分解能, および検出を想定する物体の幅から計測可能範囲 を求められることを確認した. また，本研究に用いた LRF では, $5.0 \mathrm{~m}$ までが計測可能範囲であることを確認し た.

そして，提案システムを指定されたターゲットを踏んで歩く試験に適用し，提案システムで計測した着床時刻 および，着床時刻における脚位置が妥当であることを検証した，さらに，着床時刻と着床位置が妥当であること から，取得した歩行周期時間，ストライド長および，一歩行周期における平均歩行速度が妥当であることを確認 した. 以上の結果より, 提案する歩行計測システムが歩行周期時間, ストライド長, 平均歩行速度, 歩行時の脚 の移動軌跡の取得が可能であることを示し，歩行に関する時間的指標および，空間的指標を提示可能であること を示した。

今後, 提案システムにおいて, より高精度な計測を要する場合には, その信頼性について, 高精度モーション キャプチャ等のシステムを用いた検証を行うことが必要になると考えられる.

\section{文献}

（1）厚生労働省, “平成 22 年国民生活基礎調査の概況 IV 介護の状況 2 要介護者等の状況”, 厚生労働省ホームページ, http://www.mhlw.go.jp/toukei/saikin/hw/k-tyosa/k-tyosa10/4-2.html (参照日 2012 年 6 月 28 日).

(2) 古名丈人, 島田裕之, “高齢者の歩行と転倒一疫学的調査からー”, バイオメカニズム学会誌, Vol. 30, No. 3 (2006), pp. 132-137.

（3）解良武士，“高齢者の転倒” 埼玉理学療法, Vol. 9, No. 1 (2002), pp. 7-13.

（4）佐賀県健康増進課, “佐賀県介護予防運動器の機能向上評価指標の説明と測定方法について”, 佐賀県庁ホームペー ジ, http://www.pref.saga.lg.jp/web/var/rev0/0051/2903/manyuaru.pdf (参照日 2012 年 6 月 28 日).

(5) 高知市健康づくり課, “11 高知市における介護予防の取り組み いきいき百歳応援講座を実施して〜”, 高知県庁ホ ームページ, http://www.pref.kochi.lg.jp/ hofuku/forum/tiikihoken/tiken/tiken_h1411.pdf (参照日 2012 年 6 月 28 日).

(6) 高見正利, 福井图彦, “床反力計による健常者歩行の研究一特に年齢および性別による違いについて一”, リハビリ テーション医学, Vol. 24, No. 2 (1987), pp. 31-39.

(7) 飯盛仁志, “歩行における前傾姿勢が下肢筋の筋活動量に及ぼす変化 高齢者歩行との比較検討”, 日本医科大学䧱 誌，Vol. 61, No. 1 (1994), pp. 17-25.

（8）嶺也守寬，小林吉之，高嶋孝倫，藤本浩志，“計測用装具を用いた痮性麻痺の歩容解析に関する研究”, 日本機械学 会論文集 C 編，Vol. 72, No. 722 (2006), pp. 3280-3285.

（9）江原義弘，山本澄子，臨床歩行計測入門 (2008), 医歯薬出版.

(10) 吉備国際大学河村顕治研究室, “ゼミ生の動作解析風景”, 吉備国際大学河村顕治研究室ブログ, http://blog.goo.ne.jp/ kawamura_md/e/d5fd7b923b24aed670e4a2ba33e923df (参照日 2012 年 7 月 9 日)

(11) Nicola B and Huosheng H, "Multisensor-Based Human Detection and Tracking for Mobile Service Robots", IEEE Transactions on Systems, Man and Cybernetics, Part B, Vol.39, No.1 (2009), pp. 167-181.

(12) 工業技術院 製品科学研究所, “AIST 人体寸法データベース 1991-92”, AIST 人体寸法データベース 1991-92, http://riodb.ibase.aist.go.jp/dhbodydb/91-92/ (参照日 2012 年 10 月 15 日).

(13) 橋本雅文, 尾崎将崇, 横山巧, 高橋和彦, “マルチ移動ロボットによるレーザベースト歩行者追跡”, 日本機械学会 論文集 C 編，Vol. 78, No. 786 (2012), pp. 220-234. 